\title{
A TWO-YEAR SURVEY ON MOSQUITOES OF LEBANON
}

\author{
KNIO K.M.*, MARKARIAN N.*, KASSIS A.** \& NUWAYRI-SALTI N.**
}

\section{Summary:}

A total of 6,500 mosquitoes were identified during a two-year survey (1999-2001) in Lebanon, and these belonged to twelve species: Culex pipiens, Cx. laticinctus, Cx. mimeticus, Cx. hortensis, Cx. judaicus, Aedes aegypti, Ae. cretinus, Ochlerotatus caspius, Oc. geniculatus, Oc. pulchritarsis, Culiseta longiareolata and Anopheles claviger. Culex pipiens was the most predominant species in Lebanon, collected indoors and outdoors. It was continuously abundant and active throughout the year. Culex judaicus was a small and rare mosquito and it is reported to occur for the first time in Lebanon. On the coastal areas, Ochlerotatus caspius was very common, and proved to be a complex of species as two forms were detected. One of the vectors of malaria, Anopheles claviger, was collected from May to September, from eight sites in Lebanon. Its breeding sites were restricted to fresh, cool, and clean water in pools and wells. Most of these breeding sites were in the populated Metn County where a few indigenous cases of malaria were reported from 1997 2000. This shows that the reported malaria cases were not imported, but caused by the bites of locally infected Anopheles females.

KEY WORDS : mosquito, Culex, Anopheles, malaria, Lebanon.
Résumé : Les moustiques du Liban : RÉsultats De DeuX ANS DE RÉCOLTES

Au cours d'une période d'observation de deux ans (1999-2001), 6500 moustiques ont été identifiés au Liban et répartis en 12 espèces: Culex pipiens, Cx. laticinctus, Cx. mimeticus, Cx. hortensis, Cx. judaicus, Aedes aegypti, Ae. cretinus, Ochlerotatus caspius, Oc. geniculatus, Oc. pulchritarsis, Culiseta longiareolata and Anopheles claviger. Culex pipiens, l'espèce prédominante, a été collectée à l'extérieur et à l'intérieur. Elle a été trouvée abondante et active tout au long de l'année. Culex judaicus, espèce petite et rare, a été observée et identifiée pour la première fois au Liban. Dans les zones côtières, il s'est avéré que l'espèce Ochlerotatus caspius, très communément observée, était en fait un complexe car deux formes ont été identifiées. Anopheles claviger, porteur de malaria, a été collecté de mai à septembre sur huit sites libanais. Leur habitat de prédilection était l'eau claire et froide des puits et bassins. La plupart des sites concernés se trouvent dans le comté du Metn où quelque cas de malaria autochtones ont été rapportés entre 1997 et 2000, ceci prouvant bien l'implication des anophèles femelles localement infectées.

MOTS CLÉS : moustique, Culex, Anopheles, paludisme, Liban.
M osquitoes are of great economic importance because many act as vectors for a number of human diseases, such as malaria, dengue, filariasis, and several types of encephalitis including West Nile fever (Service, 1993). With the constantly changing environment, the epidemiology of mosquitoborne diseases is also modified. Global warming, periodic flooding and deforestation have opened new habitats to mosquitoes which show high plasticity in their breeding behavior and readily spread their distribution. In fact, sporadic malaria outbreaks have been reported in non-endemic countries and transmission of the disease was caused by the bite of a locally infected Anopheles species (Zucker, 1996).

\footnotetext{
* Biology Department, Faculty of Arts \& Sciences, American University of Beirut, Beirut, Lebanon.

** Department of Human Morphology, Faculty of Medicine, American University of Beirut, Beirut, Lebanon.

Correspondence: Dr Khouzama Knio.

Tel.: 961350000 (ext. 3886) - Fax: 9611351706

E-mail:kknio@aub.edu.lb
}

In Lebanon, several mosquito-borne diseases mainly malaria and dengue were endemic until the 1950's when the government launched a mosquito eradication program (Matossian \& Ibrahim, 1974). No cases of dengue and malaria were reported afterward; however, since 1997, several incidences of local malaria have occurred in some populated areas of Lebanon (Hamadeh, 1997). It seems that malaria still poses a threat to the country especially that the disease was never eradicated from the neighboring countries. To examine the transmission of diseases by mosquitoes in Lebanon, it is critical to start by studying the taxonomy, distribution and abundance of these vectors, especially that knowledge of the mosquito species in Lebanon is very patchy and dates from the 1940's and 70's (Parr, 1943; Matossian \& Ibrahim, 1974).

The aims of this study are to update and evaluate the current status of mosquito species in Lebanon, and to determine the breeding sites, abundance and distribution of the Lebanese mosquitoes, with special emphasis on the malaria vectors. 


\section{MATERIALS AND METHODS}

tarting 1999, a two-year survey on mosquito species was initiated in Lebanon. Mosquitoes were collected from all provinces and sectors of the country, with the exception of some inaccessible areas in the South (Fig. 1). The aquatic larvae and pupae were collected using dippers (Bioquip), from different breeding sites, such as rocky pools, ponds, swamps, irrigation ditches, streams... They were brought to the laboratory and reared into adults using mosquito breeders (Bioquip).

Adult mosquitoes were collected from outdoors and indoors using various methods, such as vials, aspirators, human bait technique, and mosquito traps (Standard New Jersey Light Trap, and Heavy Duty EVS $\mathrm{CO}_{2}$ Mosquito Trap by Bioquip).

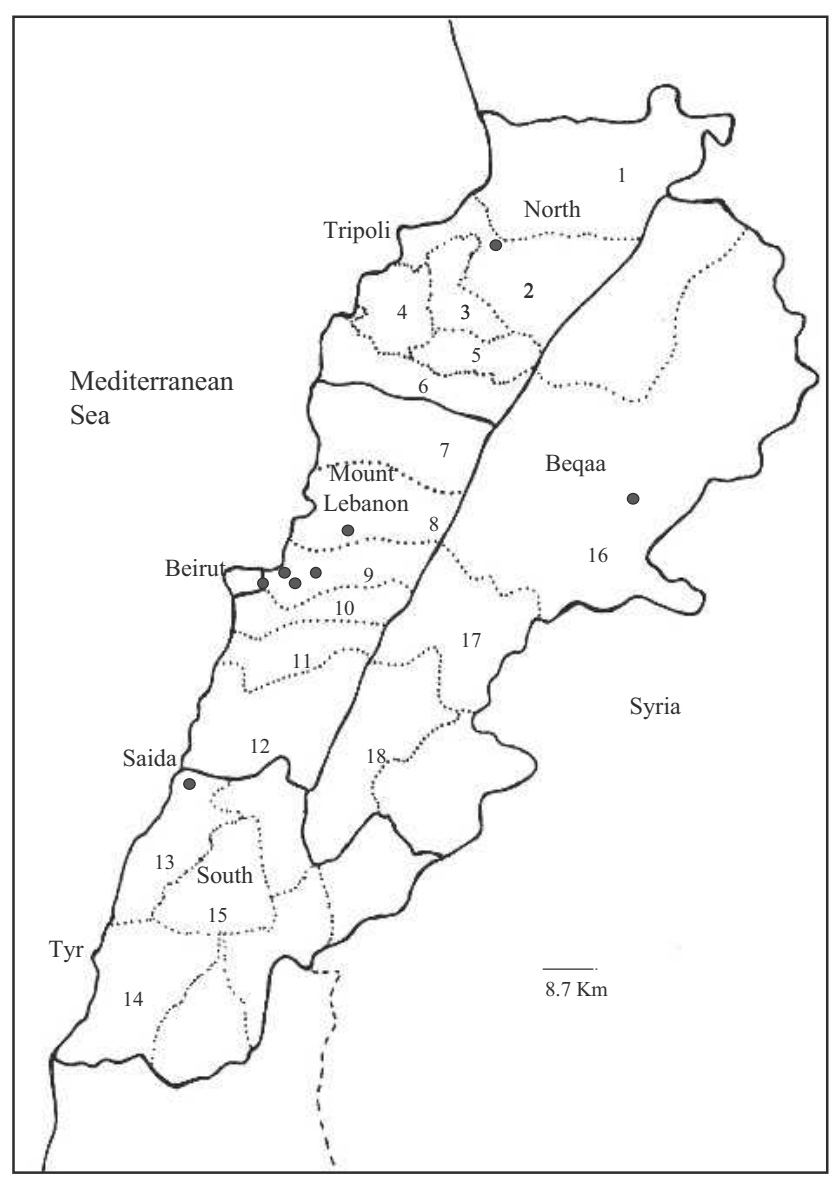

Fig. 1. - Map of Lebanon showing the different counties where mosquitoes were collected for this survey, and showing the sites of collection of Anopheles claviger.

(1) Akkar Co.; (2) Tripoli Co.; (3) Zgharta Co.; (4) Koura Co.;

(5) Bcharre Co.; (6) Batroun Co.; (7) Jbeil Co.; (8) Kesrouan Co.;

(9) Metn Co.; (10) Baabdah Co.; (11) Aaley Co.; (12) Chouf Co.;

(13) Saida Co.; (14) Tyr Co.; (15) Nabatiyeh Co.; (16) Baalback Co.;

(17) Zahleh Co.; (18) West Beqaa Co.

( denotes sites of collection of An. claviger).
In order to estimate changes in mosquito density throughout the year, periodic indoor house collections from July 1999 to July 2000 were made weekly in five selected houses situated in Beirut and its suburbs: Ain El Roumaheh (Greater Beirut), Sabtieh (Greater Beirut), Zalka (Metn Co., Mount Lebanon), Nabay (Metn Co., Mount Lebanon), and Rabwe (Metn Co., Mount Lebanon). The weekly indoor collections involved the same catch efforts per unit time in each house: number of actively biting and resting mosquitoes caught during five hours after sunset.

The taxonomy of the collected mosquitoes were determined using keys by Dubose \& Cutin (1965), Harbach (1985, 1988), Jayson (1992), Glick (1992), and Samanidou-Voyadjoglou \& Harbach (2001) after an initial consultation and species confirmation by Dr Harbach (NHM, London). Voucher specimens were preserved in the NHM, American University of Beirut.

\section{RESULTS}

\begin{abstract}
total of 6,500 mosquitoes were collected from various sites in Lebanon. The mosquitoes belon1 ged to two subfamilies, Culicinae and Anophelinae, and twelve species: a - Culex (Culex) pipiens; b - Cx. (Culex) laticinctus; c - Cx. (Culex) mimeticus; $\mathrm{d}-$ CX. (Maillotia) hortensis; e - CX. (Neoculex) judaicus; f - Ochlerotatus (Ochlerotatus) caspius; g - Oc. (Finlaya) geniculatus; h - Oc. (Ochlerotatus) pulchritarsis; i - Aedes (stegomyia) cretinus; j - Ae. (Stegomyia) aegypti; $\mathrm{k}$ - Culiseta (Allotheobaldia) longiareolata; and 1 - Anopheles (Anopheles) claviger.

The regions with GPS readings where different mosquito species were collected are indicated in the text below with the exception of $C x$. pipiens which was extremely widespread in the country. For this reason, the counties and number of sites per county are indicated for the latter species.
\end{abstract}

\section{a - Culex (Culex) pipiens Linnaeus, 1758}

Greater Beirut: 442F:15M Beirut (20 sites). Mount Lebanon: 597F:36M (Aaley Co.) (14 sites); 514F:12M (Baabdah Co.) (4 sites); 292F:18M (Chouf Co.) (12 sites); 385F:40M (Kesrouan Co.) (14 sites); 588F:31M (Metn Co.) (22 sites); 205F:2M (Jbeil Co.) (5 sites). North Lebanon: 78F (Batroun Co.) (2 sites); 274F:5M Koura (Co.) (6 sites); 112F:5M (Tripoli Co.) (4 sites); 10F:4M (Akkar Co.) (2 sites); 10F (Zgharta Co.) (2 sites). South Lebanon: 156F:10M (Saida Co.) (6 sites); 94F:2M (Nabatiyeh Co.) (2 sites); 96F:4M (Tyr Co.) (4 sites). Beqaa Valley: 172F:13M (Zahle Co.) (5 sites); 507F:12M (Baalback Co.) (6 ); 329F:12M (West Beqaa Co.) (4 sites).

Culex pipiens was the most predominant and widespread species in Lebanon, collected indoors and outdoors, and comprising ca. $78 \%$ of the total collected 


\begin{tabular}{lrrrc}
\hline \multicolumn{1}{c}{ Species } & $\begin{array}{c}\text { Total } \\
\text { number }\end{array}$ & Females & Males & Percentage \\
\hline Culex pipiens & 5,082 & 4,861 & 221 & 78.2 \\
Cx. laticinctus & 142 & 77 & 65 & 2.18 \\
Cx. mimeticus & 99 & 51 & 48 & 1.52 \\
Cx. hortensis & 39 & 22 & 17 & 0.60 \\
Cx. judaicus & 33 & 22 & 11 & 0.51 \\
Ochlerotatus caspius & 769 & 526 & 243 & 11.83 \\
Oc. geniculatus & 20 & 20 & - & 0.31 \\
Oc. pulchritarsis & 2 & 2 & - & 0.03 \\
Ae. cretinus & 34 & 32 & 2 & 0.52 \\
Ae. aegypti & 1 & - & 1 & 0.01 \\
Culiseta longiareolata & 185 & 133 & 52 & 2.85 \\
Anopheles claviger & 94 & 66 & 28 & 1.45 \\
\hline
\end{tabular}

Table I. - Total number and percentages of the 12 mosquito species collected in Lebanon during 1999-2001.

\begin{tabular}{lrc}
\hline \multicolumn{1}{c}{ Species } & Number & Percentage \\
\hline Culex pipiens & 1,466 & 97.93 \\
Cx. laticinctus & 8 & 0.53 \\
Cs. longiareolata & 10 & 1.34 \\
Aedes cretinus & 1 & 0.07 \\
Anopheles claviger & 2 & 0.13 \\
\hline
\end{tabular}

Table II. - Number and percentage of mosquito species collected indoors in the five monitored houses, during 1999-2000.

mosquitoes (Table I). It was distributed throughout the country and found at all altitudes. Its breeding sites were diverse, ranging from artificial containers such as cans filled with rain water, water reservoirs, garden pools, to rivers, ponds, and irrigation ditches.

This species was continuously abundant and active throughout the year. Monitoring mosquitoes in five selected houses throughout the year demonstrated that Cx. pipiens was the most abundant mosquito indoors, accounting for $97.9 \%$ of the catches (Table II). Its behavior was anthropophilic, endophagic, and endophilic. In 1999-2000, the changes in population density of Cx. pipiens indoors, as observed in the monitored houses, showed that the female mosquitoes were active throughout the year as long as the temperature was favourable (Fig. 2). An increase in the population of $C x$. pipiens females was detected in November when the temperature started to drop. This could be explained by the fact that the females appeared to be the overwintering stage, and remained active and did not hibernate when the winter was wild.

b - Culex (Culex) laticinctus Edwards, 1913

Mount Lebanon: 4F Ainab (Aaley Co.) (33 45 963'N; 3532 636'E); 1F Bolonia (Metn Co.) (33 54 656'N; 3544 066'E); 2F:1M Chehim (Chouf Co.) (33 37 086'N; 3529 160'E); 6F Deir El Kamar (Chouf Co.) (33 41 802'N; 3533 928'E); 6F Doha (Chouf Co.) (33 45 461'N; 3528 716'E); 2F Kornet El Hamra (Kesrouan Co.) (33 56 203'N; 3539 065'E); 33F:21M Yahchouch (Kesrouan Co.) (34 03 998'N; 3543 897’E); 5F:6M Nahr El Kalb (Metn Co.) (33 56 779'N; 3538 008'E); 4F Rabwe (Metn Co.) (33 53 048'N; 3534 320'E); 2F:2M Ghazir (Kesrouan Co.) (34 01 159'N; 3539 324'E); 1M Jiye (Chouf Co.) (33 39 796'N; 3525 563'E). South Lebanon: 3F Kasmieh (Tyr Co.) (33 19 314'N; 3517 194'E); 5F:2M Saida (Saida Co.) (33 34 702'N; 3525 030'E); 3F:1M Ras El Ain (Tyr Co.) (33 $13688^{\prime} \mathrm{N} ; 3513$ 061'E). North Lebanon: 1F:1M Enfe (Koura Co.) (34 21 534'N; 3543 818'E); 3F Kousba (Koura Co.) (34 18 035’N; 3551 017'E). Greater Beirut: 3F:2M Sabtieh (33 51 721'N; 3534 826'E). Beqaa Valley: 8F:4M Btedaai (Baalback Co.) (34 06 623'N; 3606 116'E); 3F:7M Chlifa (Baalback Co.) (34 05 037'N; 3606 027'E).

This species was collected from April to November, as adults from indoors and as larvae from outdoor water sources. The larvae were found to breed in rivers, such

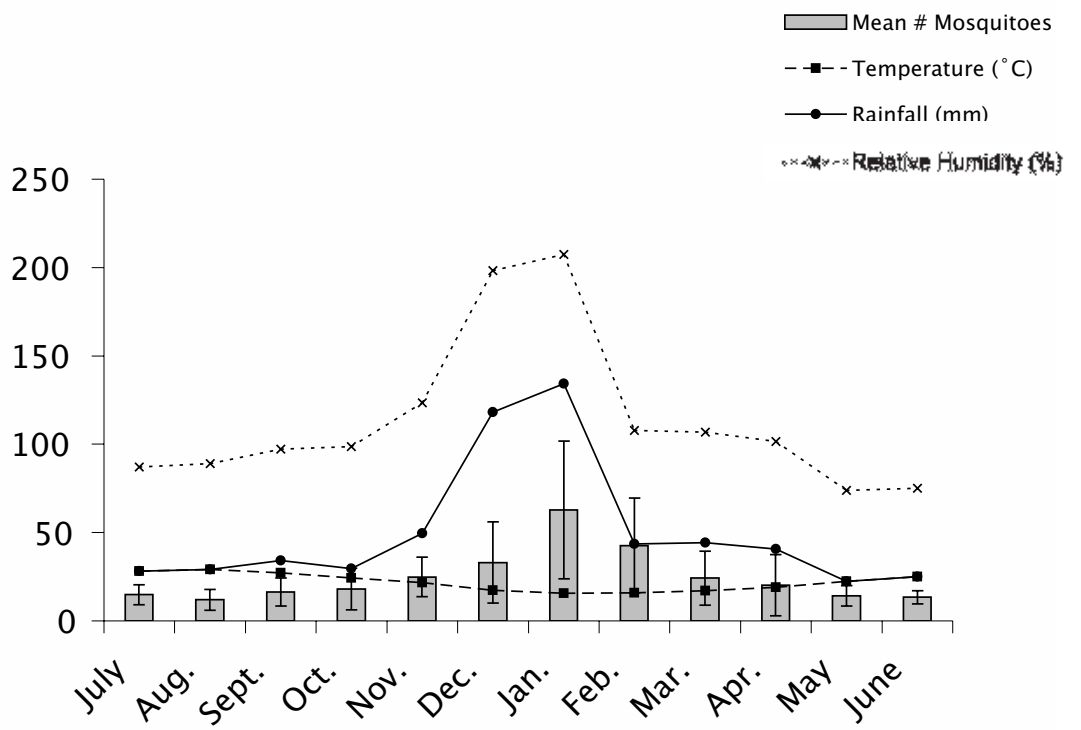

Fig. 2. - Changes in the population density of Culex pipiens females as observed in the monitored houses during 1999-2000. 
as Nahr El Kalb, in garden pools, in artificial containers, such as water filled barrels, in water reservoirs, and in irrigation ditches. The adults were collected indoors, and were found to rest on indoor walls. In fact, $C x$. laticintus was found to be the third most abundant mosquito species indoors, but it was found at a low density and accounted for only $0.53 \%$ of the catches in the monitored houses (Table II). Therefore, this species also exhibits anthropophagic, endophagic, and endophilic behaviours, but with a much lesser degree than Cx. pipiens.

c - Culex (Culex) mimeticus Noè, 1899

North Lebanon: 43F:46M Oyoun El Samak (Akkar Co.) (34 26 630'N; 3602 253’E). Mount Lebanon: 8F:2M Yahchouch (Kesrouan Co.) (34 03 998'N; 3543 897’E).

This species was only collected outdoors in the summer, in natural and large fresh water sources, namely, river banks.

d - Culex (Maillotia) hortensis Ficalbi, 1899

Greater Beirut: 2M Achrafieh (33 53 467'N; 3531 015'E). Beqaa Valley: 3F:3M Ras El Ain (Baalback Co.) (34 00 $334^{\prime} \mathrm{N} ; 3613$ 269'E); 5F:3M Chlifa (Baalback Co.) (34 05 037'N; 3606 027'E); 4F:2M Btedaai (Baalback Co.) (34 06 623’N; 3606 116'E); 2F:4M Ammiq (West Beqaa Co.) (33 $43265^{\prime} \mathrm{N}$; 3546 667'E). North Lebanon: 4F:1M Bebnine (Akkar Co.) (34 29 901'N; 35 59 724'E). South Lebanon: 1F:1M Kasmieh (Tyr Co.) (33 19 314;N; 3517 194'E). Mount Lebanon: 3F:1M Yahchouch (Kesrouan Co.) (34 03 998'N; 3543 897'E).

This species preferred mainly natural fresh water sites for breeding purposes and was found from May to September. Larvae were collected from the Ammiq swamp, irrigation ditches, and large water reservoirs next to river banks. Only a few (5) adults were colleted from indoor houses although this species was not reported in the monitored houses. Culex hortensis comprised $0.60 \%$ of the total collected mosquitoes, and was most prominent in the field (Table I).

e - Culex (Neoculex) judaicus Edwards 1926

Mount Lebanon: 20F:9M Nahr Ibrahim (Kesrouan Co.) (34 04 648'N; 3544 135'E); 3M Yahchouch (Kesrouan Co.) (34 03 998'N; 3543 897'E). South Lebanon: 2F Qâsmiyé (Tyr Co.) (33 19 314'N; 3517 194'E).

This is a very small mosquito that was collected in the North and South of Lebanon, from April to September, and only in the field, in river banks or in water reservoirs next to rivers.

f - Ochlerotatus (Ochlerotatus) caspius (Pallas, 1771) North Lebanon: 7F Batroun (Batroun Co.) (34 15 109'N; 3539 251'E); 25F:4M Chekka (Batroun Co.) (34 19 525'N; 3543 261'E); 90F:78M Enfe (Koura Co.) (34 $21714^{\prime} \mathrm{N}$; 3543 638'E); 3F Saidat El Nourieh (Koura Co.) (34 18 630'N; 3540 592'E); 106F:35M Qalamoun (Tripoli Co.) 93423 922'N; 3547 826’E); 2F:2M El Mina (Tripoli Co.)
(34 26 976'N; 3548 579'E); 3F:2M Sanani Island (Tripoli Co.) (34 $29257^{\prime} \mathrm{N} ; 3546$ 696'E); 12F:11M Rabbit Island (Tripoli Co.) (34 29 808'N; 3546 364'E). Mount Lebanon: 27F Berbâra (Jbeil Co.) (34 12722 'N; 3538 397’E); 46F:41M Hâlât (Jbeil Co.) (34 05 539'N; 3538 807'E); 4F Jbeil (Jbeil Co.) (34 07 859'N; 3538 375'E); 8F:3M Nahr Ibrahim (Jbeil Co.) (34 03 943’N; 3539 130'E); 1F:1M Nahr El Kalb (Metn Co.) (33 57 150'N; 3536 089'E); 74F:2M Maameltein (Kesrouan Co.) (34 00 $713^{\prime} \mathrm{N}$; 3538 375'E); 16F Aakaibe (Kesrouan Co.) (34 03 404'N; 3537 987’E); 3M Kartaba (Jbeil Co.) (34 05 873 'N; 3550 520'E); 11F:9M Jiyé (Chouf Co.) (33 40 037'N; 3524 884'E); 25F:18M Ouâdi ez Zeini (Chouf Co.) (33 37 563’N; 3524 204'E); 38F:30M Saadiyât (Chouf Co.) (33 $41635^{\prime} \mathrm{N} ; 3525$ 366'E). South Lebanon: 12F:4M Nahr El Kasmieh (Tyr Co.) (33 19 314'N; 3517 194'E); 12F Rachidiyeh (Tyr Co.) (33 14 172'N; 3512 619'E). Greater Beirut: 4F Manara (33 53 542'N; 3528 $\left.147^{\prime} \mathrm{E}\right)$.

Ochlerotatus caspius was mainly captured from the sea shore, from mid April to October. The larvae were found to breed in salty rocky pools and adult females became very active around sunset at high densities, and were capable of inflicting painful bites. This species was also found in natural fresh water river banks, mainly in the rivers close to the coast. It was not captured indoors, and appeared to have a strong anthropophilic, exophagic, and exophilic behaviors. With respect to its density, it was found to be the second most abundant mosquito, accounting for about $12 \%$ of the total catches (Table I).

Ochlerotatus caspius appeared to be a complex of species. Morphological differences were detected between the population in the South of Lebanon from the Kasmieh River and the rest of the populations. The specimens collected at Kasmieh River matched the typical description of Oc. caspius (Dubose \& Curtin, 1965; Lambert et al., 1990) in having on the mesonotum all fawn-colored scales and two submedial lines of whitish scales running along the length of the scutum. Also, the abdominal terga showed transverse basal bands of pale scales, in addition to a pale, median, dorsal stripe. The rest of the specimens differed in having a scutum covered with scales golden-brown in color, which was similar to the description of Ochlerotatus (Ochlerotatus) mariae (Sergent \& Sergent, 1903) (Dubose \& Curtin, 1965; Samanidou-Voyadjoglou \& Harbach, 2001), but they differed from the description of Oc. mariae because of the absence of scales on the metameron. Therefore, they seem to be a species near caspius and thus remain to be classified under Oc. caspius, which seems to be a species complex.

g - Ochlerotatus (Finlaya) geniculatus (Olivier, 1791) North Lebanon: 12F Ehden (Zghorta Co.)(34 17 887'N; 3558 838'E). Mount Lebanon: 8F Souq El Gharb (Aaley Co.) (33 $\left.47393^{\prime} \mathrm{N} ; 3533731^{\prime} \mathrm{E}\right)$. 
This species was only caught during the month of June both in the field and indoors, at high elevations in Mount Lebanon.

h - Ochlerotatus (Ochlerotatus) pulchritarsis (Rondani, 1872)

Mount Lebanon: 2F Qlaiaât (Kesrouan Co.) (33 58 375'N; 3442 409'E)

This is a rare mosquito that was captured during the month of June.

i - Aedes (Stegomyia) cretinus (Edwards, 1921)

Mount Lebanon: 3F Broummana (Metn Co.) (33 52 $807^{\prime} \mathrm{N}$; 3538 267'E); 3F Douar (Metn Co.) (33 54 496'N; 3541 546'E); 2F Baabda (Baabda Co.) (33 49 901'N; 3532 702'E); 2F:1M Kafarchima (Baabda Co.) (33 48 $600^{\prime} \mathrm{N}$; $\left.3532745^{\prime} \mathrm{E}\right)$; 4F Naqqach (Metn Co.) (33 55 566'N; 3535 373'E); 1F Râbié (Metn Co.) (33 55 257'N; 3535 312'E); 10F:2M Souq El Gharb (Aaley Co.) (33 48 393'N; 3533 731'E); 4F Sahel Alma (Kesrouan Co.) (33 59 971'N; 3539 281'E). Greater Beirut: 2F Achrafieh (33 $53467^{\prime} \mathrm{N}$; $\left.3531015^{\prime} \mathrm{E}\right)$.

This species was found at low density and was caught outdoors and indoors, from May to October. It accounted for $0.07 \%$ of the catches made in the monitored houses. It appeared to have anthropophilic and endophagic behaviours, and seemed to be distributed from sea level to medium altitude mountains in Mount Lebanon.

j - Aedes (Stegomyia) aegypti (Linnaeus, 1762)

Mount Lebanon: 1M Kartaba (Jbeil Co.) (34 05 873'N; 3550 520'E).

Only one male was collected outdoors next to a river bank.

k - Culiseta (Allotheobaldia) longiareolata (Macquart, 1838)

Mount Lebanon: 2F Hadath (Baabda Co.) (33 50607 'N; 3531 979'E); 1F Hâzmiyé (Baabda Co.) (33 51 517’N; 3532 329'E); 1F:2M Ain Saâdé (Metn Co.) (33 52 037'N; 3535 088'E); 1M Bayyada (Metn Co.) (33 55 $325^{\prime} \mathrm{N}$; 3538 679'E); 9F:12M Nahr El Kalb (Metn Co.) (33 56 779'N; 3538 008'E); 2F Zouk (Metn Co.) (33 56 205'N; 3536 024’E); 8F:1M Zalqa (Metn Co.) (33 54 $117^{\prime} \mathrm{N}$; 3534 344'E); 1F Hammana (Aaley Co.) (33 49 $474^{\prime} \mathrm{N}$; 3543 847'E); 20F:5M Nahr Ibrahim (Kesrouan Co.) (34 $04648^{\prime} \mathrm{N} ; 3544$ 135'E); 3F Yahchouch (Kesrouan Co.) (34 03 998'N; 3543 897'E); 4F Tabarja (Kesrouan Co.) (34 01 994'N; 3437 469'E); 6F:2M Okaiba (Jbeil Co.) (34 03 609'N; 3538 418'E). Greater Beirut: 16F:5M Beirut (33 53 504'N; 3529 855'E); 3F Ain El

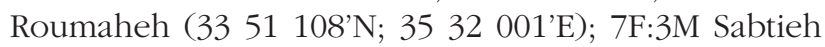
(33 $51721^{\prime} \mathrm{N}$; 3534 826'E) . Beqaa Valley: 18F:10M Labweh (Baalback Co.) (34 12 463'N; 3622 589'E); 3F Btedaai (Baalback Co.) (34 06 623’N; 3606 116'E); 4F:4M Chlifa (Baalback Co.) (34 05 037’N; 3606 027’E); 1M Nahle (Baalback Co.) (34 01 240’N; 3615 627’E);
6F:4M Ras El Ain (Baalback Co.) (34 00 334’N; 3613 269'E). South Lebanon: 4F Saida (Saida Co.) (33 34 702'N; 3525 030'E); 12F:2M Qâsmiyé (Tyr Co.) (33 19 314 'N; 3517 194'E); 3F Maaraké (Tyr Co.) (33 16 295'N; 3518 550'E).

This large mosquito was caught from March to September, both indoors and as larvae in the field. The larvae bred in fresh, clean water sources such as irrigation ditches, water reservoirs, garden pools, water cans near Nahr Ibrahim, and water filled barrels.

Culiseta longiareolata accounted for $2.85 \%$ of the collection (Table I). Although it represented only $1.34 \%$ of the mosquitoes collected in the monitored houses (Table II), it was found to be the second most abundant mosquitoes indoors. Its behaviour appeared to be anthropophilic, endophagic, and endophilic.

\section{1 - Anopheles (Anopheles) claviger (Meigen, 1804)}

Mount Lebanon: 1F Ain El Saadeh (Metn Co.) (33 52 037'N; 3535 088'E); 1F Besalim (Metn Co.) (33 53 820 'N; 3534 475'E); 3F:2M Yahchouch (Kesrouan Co.) (34 03 998'N; 3543 897’E); 6F Broummana (Metn Co.) (33 52 807'N; 3538 267'E). Greater Beirut: 2F Sabtieh (33 $51721^{\prime} \mathrm{N}$; 3534 826'E). Beqaa Valley: 3F Nahle (Baalback Co.) (34 01240 'N; 3615 627'E). South Lebanon: 2M Nahr El Awally (Saida Co.) (33 34 702'N; 3525 030'E). North Lebanon: 50F:24M Oyoun El Samak (Akkar Co.) (34 26 630’N; 3602 253’E).

This species was caught from late April to November both indoors as adults and as larvae in the field. The larvae were found only to breed in cold, fresh and clean water sources, such as wells, natural pools and clean puddles next to river banks.

Anopheles claviger accounted for $1.45 \%$ of the total collection (Table I) and $0.13 \%$ of the catches in the monitored houses (Table II). Gravid females were collected from houses in highly populated areas, in all of the three sites in the Metn Co. of Mount Lebanon, and in one of the monitored houses (Sabtieh) in Greater Beirut (Fig. 1).

\section{DISCUSSION}

T The results of the survey demonstrated that $C x$. pipiens was the most common and abundant mosquito species in Lebanon, both indoors and outdoors. Similarly, Parr (1943) previously reported that Culex pipiens molestus (Forskal 1775) was "a domestic species whose distribution probably extends to every town and village in Syria and Lebanon". In fact, Culex pipiens was reported to be very widely distributed in the whole Paleartic and eastern areas of the Afrotropical Region such as Yemen and the southwestern part of the Saudi Arabia (Harbach, 1988). Moreover, Cx. pipiens molestus has been identified in Lebanon by 
Matossian \& Ibrahim (1974) who reported that it was responsible for the transmission of the West Nile Virus infection in Egypt, and other countries in the Eastern Mediterranean.

Culex laticinctus was the second most abundant Culex species collected indoors and outdoors, yet with a much lower density. In accordance with our results, this species was reported to be mainly paleartic (Harbach, 1988), and was previously reported in Lebanon by Parr (1943) and Harbach (1985). In 1943, Parr noted that Cx. laticinctus started to breed in late spring and became abundant in coastal areas during the summer. This species is not known to be involved in the transmission of diseases.

Culex mimeticus was also reported by Parr (1943) who found it common in the summer months in coastal and inland areas of Lebanon. On the other hand, in 1974, Matossian \& Ibrahim did not observe its presence. Our results indicate the current rarity of this mosquito and its association with wild habitats.

Regarding the rest of the Culex species, they were found at low densities in Lebanon. Culex hortensis was also reported by Parr (1943) who found it abundant in the spring. Our results showed its occurrence from April to September, in natural aquatic habitats. As for CX. judaicus, it was found to be a rare species in Lebanon. This species was not previously reported to occur in Lebanon, and thus we report it as a new record. It was noted as a new record in Jordan by Amr et al. (1997). As for other Culex species, Parr (1943) reported the occurrence of Culex (Culex) univittatus Theobalt 1901 in different areas of the country during the summer and fall. This species might have become rare as it was not encountered in our survey and during the work of Matossian and Ibrahim in 1974. Moreover, Harbach $(1985,1988)$ reported the occurrence of three Culex species that we did not encounter in our survey. These species are: Culex (Culex) perexiguus Theobald 1903, Culex (Culex) theileri Theobald 1903, and Culex (Culex) tritaeniorbynchus Giles, 1901. Parr (1943) did not report the presence of $C x$. perexiguus, but mentioned that he collected larvae of Cx. tritaeniorbynchus but no adults from a rain water cistern in one site of Lebanon and reported that $C x$. theileri is not common at all in Lebanon. He found a few adults of this later species in the Ammiq swamp, which is today quite altered as the water level has tremendously decreased. It could be that these species became rare due to habitat modification.

Several Ochlerotatus species were collected in this survey. Ochlerotatus caspius was found to be very common and abundant in the coastal areas. Two forms were detected; thus, this species seems to form a complex and needs further investigation. Ochlerotatus caspius has not been previously reported in Lebanon. Parr (1943) found the presence of one female Oc. mariae, and Matossian \& Ibrahim (1974) confirmed its presence. However, this could have been a misidentified Oc. caspius. Ochlerotatus caspius was reported in other Middle Eastern countries, such as Egypt (El Shazly et al., 1998) and Israel (Braverman et al., 1991).

The rest of the Ochlerotatus species, Oc. geniculatus, and Oc. pulchritarsis were less abundant. None were reported previously to occur in Lebanon. Parr (1943) mentioned the possibility of the presence of Oc. geniculatus in Lebanon, but he could not make an accurate identification as his specimen was in poor condition.

Two Aedes species were encountered in this survey. Aedes cretinus was found at low densities in both outdoors and indoors. This mosquito species was not reported previously to occur in Lebanon. On the other hand, Parr (1943) reported the presence of Ae. aegypti, which we encountered only one specimen in our survey, most probably as it occurs now at a very low density and perhaps because it was the target of eradication programs by the government. In fact, Matossian \& Ibrahim (1974) noted that several epidemics of dengue took place in Lebanon from 1861 to 1946, but none for the 25 years after, and the reasons for the disease disappearance were not fully understood. They also postulated that the eradication of Ae. aegypti vector could be the main reason.

Culiseta longiareolata was quite common in Lebanon. Parr (1943) reported the presence of Theobaldia longiareolata (Macquart), but Matossian \& Ibrahim (1974) did not report its existence in Lebanon. This species was also reported from other Middle Eastern countries such as Jordan (Khyami-Horani et al., 1999), Egypt (El Shazly et al., 1998) and Israel (Braverman et al., 1991).

One of the vectors of malaria, Anopheles claviger, was collected from May to September, from eight sites in Lebanon. The breeding sites for this species were restricted to fresh, cool, and clean water habitats. Three of these breeding sites were in Ain Saade and its surrounding areas (Metn Co.), where a few indigenous cases of malaria were reported in 1997, 1999, and 2000 (Hamadeh, 1997; El Awar, personal communication). In all these cases, the patients did not leave the country and did not have any blood transfusion. These observations clearly show that the reported malaria cases were not imported, but autochthonous and caused by the bites of locally infected Anopheles females.

Previous studies reported other Anopheles species in Lebanon, such An. (Anopheles) algeriensis Theobald 1903, An. (Anopheles) byrcanus (Pallas 1772), An. (Cellia) dthali Patton 1905, An. (Cellia) multicolor Cambouliu 1902, An. (Cellia) pulcherrimus Theobald 1902, An. (Cellia) rhodesiensis rupicola Lewis 1937, and An. (Cellia) sergentii (Theobald 1907) (Glick 1992), An. (Anopheles) marteri Senevet and Prunelle 1927, An. 
(Anopheles) sacharovi Favre 1903, and An. (Cellia) superpictus Grassi 1899 (Glick, 1992; Parr, 1943). However, these species were not collected in our survey. It could be that either they became very rare after the Mosquito Eradication Campaign in the 1960's or their breeding sites were altered.

In the 1940's, malaria vectored by several Anopheles species was hyperendemic in Lebanon, especially in the coastal regions. After the initiation of the Malaria Eradication Program, eradication was achieved in Lebanon as no indigenous cases of malaria were observed after 1963 (Matossian \& Ibrahim, 1974). However, because of the resurgence of malaria in many parts of the world, and because the disease was never completely eradicated from neighbouring countries, such as Syria and Israel (Schwartz, 1994), malaria still poses a threat to Lebanon, especially that the returning tourism and post-civil war influx from different countries, such as Africa, have made the protozoan reservoir available. Our findings demonstrate the occurrence of the malaria vector at low densities in a few populated regions of Mount Lebanon where tourism is common. This indicates that malaria surveillance should be strengthened and the vector breeding sites should be closely monitored.

\section{ACKNOWLEDGEMENTS}

The authors would like to thank Dr R. Harbach (NHM, London) who helped in the initial identification of the mosquitoes, and Miss H. Zournajian who helped in processing the collected specimens. This research was made possible because of a 'URB' research grant from the American University of Beirut.

\section{REFERENCES}

Amr Z.S., Al-Khalidi Y. \& ARBAJI A. Larval mosquitoes collected from northen Jordan and the Jordan Valley. Journal of the American Mosquito Control Association, 1997, 13, 375-378.

Braverman Y., Kitron U. \& Killick-Kendrick R. Attractiveness of vertebrate hosts to Culex pipiens (Diptera: Culicidae) and other mosquitoes in Israel. Journal of Medical Entomology, 1991, 28, 133-138.

Dubose W.P. \& CurTin T.J. Identification keys to the adult and larval mosquitoes of the Mediterranean area. Journal of Medical Entomology, 1965, 1, 349-355.

El Shazly A.M., Ali M.E., Handoussa A.E. \& AbDalla K.F. Studies on culicine larvae in Mansoura Center, Dakahlia Governorate. Journal of the Egyptian Society of Parasitology, 1998, 28, 839-847.

GLICK J.I. Illustrated key to the female Anopheles of Southwestern Asia and Egypt (Diptera: Culicidae). Mosquito Systematics, 1992, 17, 83-107.
Hamadeh R. Report on transmitted diseases. EpiNews - Lebanese Epidemiological Newsletter, 1997, 4, 6.

Harbach R.E. The Mosquitoes of the subgenus Culex in Southwestern Asia and Egypt (Diptera:Culicidae). Contribution of the American Entomological Institute, 1988, 24, 1240.

HaRbaCH R.E. Pictorial keys to the genera of mosquitoes, subgenera of Culex and the species of Culex (Culex) occurring in Southwestern Asia and Egypt, with a note on the subgeneric placement of Culex deserticola (Diptera: Culicidae). Mosquito Systematics, 1985, 17, 83-107.

JAYSON I.G. Illustrated key to the female Anopheles of Southwestern Asia and Egypt (Diptera: Culicidae), Mosquito Systematics, 1992, 25, 125-151.

Khyami-Horani H., Hatbeth-Bader A. \& Mohsen Z.D. Isolation of endospore-forming bacilli toxic to Culiseta longiareolata (Diptera: Culicidae) in Jordan. Letters in Applied Microbiology, 1999, 28, 57-60.

Lambert M., Pasteur N., Rioux J.A., Delalbre-Belmonte A. \& Balard Y. Aedes caspius (Pallas, 1771) et $A$. dorsalis (Meigen, 1830) (Diptera : Culicidae). Analyses morphologique et génétique de deux populations sympatriques. Preuves de l'isolement reproductif. Annales de la Societé Entomologique de France, 1990, 26, 381-398.

Matossian R. M.\& IBRAhim J. Rats, flies, and mosquitoes of Lebanon: pests, reservoirs, and vectors of disease. Lebanese Medical Journal, 1974, 27, 375-381.

PARR H.C.M. The Culicine mosquitoes of Syria and Lebanon. Bulletin of Entomological Research, 1943, 34, 245-251.

SAmanidou-Voyadjoglou A. \& Harbach R.E. Keys to the mosquitoes of Greece. European Mosquito Bulletin, 2001, 10, $13-20$.

SCHWARTZ E. Could there be a recurrence of malaria in Israel? Israel Journal of Medical Science, 1994, 30, 296-297.

SERVICE M.W. Mosquitoes (Culicidae): medical importance, in: Medical Insects and Arachnids. Lane R.P. \& Crosskey R.W. (eds), Chapman and Hall, London, 1993, 5, 196-208

ZUCKER J.R. Changing patterns of autochthonous malaria transmission in the United States: a review of recent outbreaks. Emerging Infectious Diseases, 1996, 2, 37-43.

Reçu le 10 janvier 2005 Accepté le 3 mai 2005 